\title{
Influence of the Rear Interface on Composition and Photoluminescence Yield of CZTSSe Absorbers: A Case for an $\mathrm{Al}_{2} \mathrm{O}_{3}$ Intermediate Layer
}

\author{
Antonio Cabas-Vidani,* Leo Choubrac, José A. Márquez, Thomas Unold, Matthias Maiberg, \\ Roland Scheer, Hu Li, Klaus Leifer, Robin Pauer, Evgeniia Gilshtein, Ayodhya N. Tiwari, \\ and Yaroslav E. Romanyuk
}

Cite This: ACS Appl. Mater. Interfaces 2021, 13, 19487-19496

Read Online

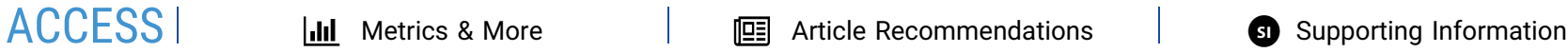

ABSTRACT: The rear interface of kesterite absorbers with Mo back contact represents one of the possible sources of nonradiative voltage losses $\left(\Delta V_{\text {oc,nrad }}\right)$ because of the reported decomposition reactions, an uncontrolled growth of $\mathrm{MoSe}_{2}$, or a nonoptimal electrical contact with high recombination. Several intermediate layers (IL), such as $\mathrm{MoO}_{3}$, TiN, and $\mathrm{ZnO}$, have been tested to mitigate these issues, and efficiency improvements have been reported. However, the introduction of IL also triggers other effects such as changes in alkali diffusion, altered morphology, and modifications in the absorber composition, all factors that can also

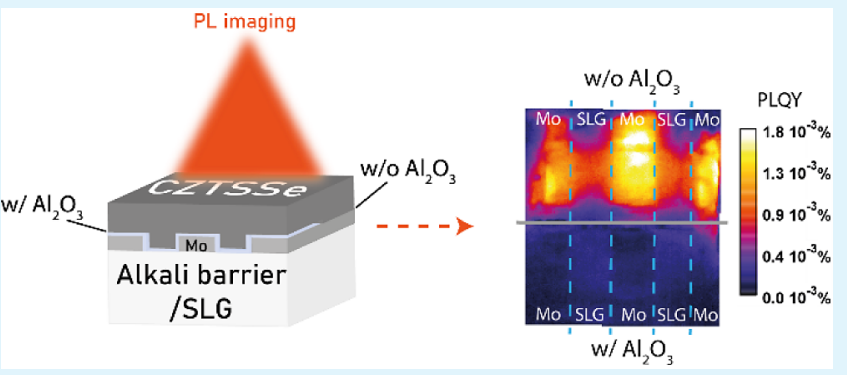
influence $\Delta V_{\text {oc,nrad. }}$ In this study, the different effects are decoupled by designing a special sample that directly compares four rear structures (SLG, SLG/Mo, SLG/ $\mathrm{Al}_{2} \mathrm{O}_{3}$, and SLG/Mo/Al $\mathrm{O}_{3}$ ) with a $\mathrm{Na}$-doped kesterite absorber optimized for a device efficiency $>10 \%$. The IL of choice is $\mathrm{Al}_{2} \mathrm{O}_{3}$ because of its reported beneficial effect to reduce the surface recombination velocity at the rear interface of solar cell absorbers. Identical annealing conditions and alkali distribution in the kesterite absorber are preserved, as measured by time-of-flight secondary ion mass spectrometry and energydispersive X-ray spectroscopy. The lowest $\Delta V_{\text {oc,nrad }}$ of $290 \mathrm{mV}$ is measured for kesterite grown on Mo, whereas the kesterite absorber on $\mathrm{Al}_{2} \mathrm{O}_{3}$ exhibits higher nonradiative losses up to $350 \mathrm{mV}$. The anticipated field-effect passivation from $\mathrm{Al}_{2} \mathrm{O}_{3}$ at the rear interface could not be observed for the kesterite absorbers prepared by the two-step process, further confirmed by an additional experiment with air annealing. Our results suggest that Mo with an in situ formed $\mathrm{MoSe}_{2}$ remains a suitable back contact for high-efficiency kesterite devices.

KEYWORDS: kesterite, CZTSSe, solar cell, back contact, photoluminescence, $\mathrm{Al}_{2} \mathrm{O}_{3}$, nonradiative recombination

\section{INTRODUCTION}

The best kesterite solar cell devices of many laboratories around the world ${ }^{1-4}$ are approaching the world record efficiency of $12.6 \%$, reached by IBM in $2013 .^{5}$ Despite all the efforts in finely optimizing the crystallization process, the problem of high $V_{\mathrm{oc}, \mathrm{SO}}$ deficit (expressed as $V_{\mathrm{oc}, \mathrm{SQ}}-V_{\mathrm{oc}}$, with $V_{\text {oc,SQ }}$ defined by the Shockley-Queisser limit) remains unresolved. The introduction of alkali metals proved to boost PV characteristics, but the minimum $V_{\mathrm{oc}, \mathrm{SQ}}$ deficit is still $0.29 \mathrm{~V}$ even for the best performing devices, ${ }^{6,7}$ whereas for CIGS, it is below $0.15 \mathrm{~V}^{8}$

Several studies suggest that the Mo back contact could be one of the factors limiting the $V_{\text {oc }}$. A possible reason is the decomposition of kesterite when in contact with the Mo layer at high temperatures. ${ }^{9}$ Mo reacts with the chalcogen vapors forming a $\mathrm{Mo}(\mathrm{S}, \mathrm{Se})_{2}$ layer, the growth of which is difficult to control as it depends on multiple interrelated factors such as the Mo layer structure, duration, and temperature of the annealing process and chalcogen overpressure in the annealing chamber. Furthermore, it is still debated whether the $\mathrm{Mo}(\mathrm{S}, \mathrm{Se})_{2} / \mathrm{CZTSSe}$ interface ensures an appropriate electrical contact. $^{10}$

The addition of an intermediate layer (IL) between the kesterite absorber and Mo has been reported to reduce or avoid the formation of $\mathrm{Mo}(\mathrm{S}, \mathrm{Se})_{2}$ by limiting the diffusion of Se to the back. Table 1 presents a collection of representative studies on the implementation of various materials as IL. While the influence on the $\mathrm{Mo}(\mathrm{S}, \mathrm{Se})_{2}$ growth varies, all papers report an increased efficiency relative to the baseline. So comes the

Received: February 4, 2021

Accepted: April 13, 2021

Published: April 19, 2021 
Table 1. Comparison of Observed Influences (Change in $\mathrm{MoSe}_{2}$ Thickness, Diffusion of Alkalis, and Other Additional Effects on Absorber Growth) Correlated with Introducing an IL between the Mo Layer and Kesterite Absorber from Recent Publications

\begin{tabular}{|c|c|c|c|c|c|}
\hline IL material/absorber type & efficiency improvement $(\%)^{a}$ & $\mathrm{Mo}(\mathrm{S}, \mathrm{Se})_{2}$ thickness & $\begin{array}{c}\text { alkalis } \\
\text { diffusion }^{b}\end{array}$ & additional effects & reference \\
\hline $\mathrm{MoO}_{3}(10 \mathrm{~nm}) / \mathrm{CZTS}$ & +19 & - & $\downarrow \mathrm{Na} \quad \uparrow \mathrm{K}$ & improved crystallization & 12 \\
\hline $\mathrm{MoO}_{3}(-) / \mathrm{CZTS}$ & +30 & $\downarrow$ & $\uparrow K$ & fewer voids at the back & 13 \\
\hline $\operatorname{TiN}(200 \mathrm{~nm}) / \mathrm{CZTS}(\mathrm{e})^{c}$ & +100 & $\downarrow$ & $\uparrow \mathrm{Na}$ & improved crystallization & 14 \\
\hline $\mathrm{Al}_{2} \mathrm{O}_{3}(3 \mathrm{~nm}) / \mathrm{CZTS}$ & +10 & $\downarrow$ & $\uparrow \mathrm{Na}$ & $\mathrm{ZnS}$ segregation from back to the surface & 15 \\
\hline $\mathrm{TiB}_{2}(30 \mathrm{~nm}) / \mathrm{CZTS}$ & +42 & $\downarrow$ & - & smaller grains & 16 \\
\hline $\mathrm{ZnO}(10 \mathrm{~nm}) / \mathrm{CZTSe}$ & +140 & - & - & bilayer formation + less secondary phases & 17 \\
\hline $\mathrm{a}-\mathrm{SiC}(10 \mathrm{~nm}) / \mathrm{CZTSe}$ & +16 & - & - & increased grain size & 18 \\
\hline
\end{tabular}

${ }^{a}$ Efficiency improvement relative to the baseline device presented in the reference. ${ }^{b} \mathrm{An}$ arrow pointing upward (downward) represents a measured increase (decrease) in the content of the indicated alkali metal in the kesterite absorber. ${ }^{c}$ Both CZTS and CZTSe absorbers have been tested. The presence of $\mathrm{TiN}$ is beneficial in both cases. The results in the table are for the CZTS absorber only.

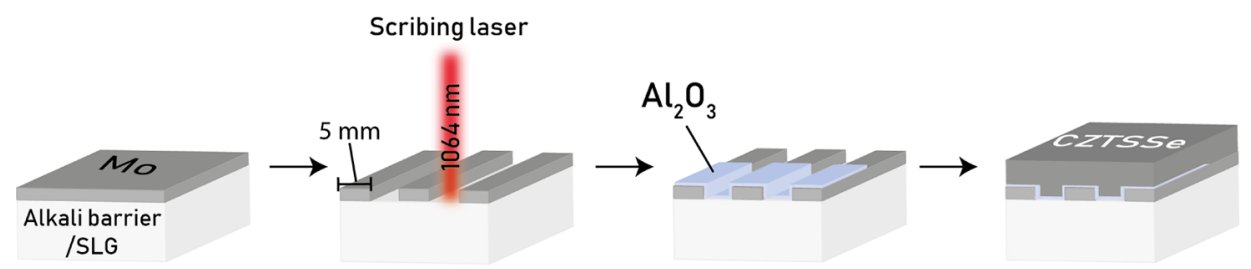

Figure 1. Process schematics to obtain the four rear structures (SLG/Mo, SLG/Mo/ $\mathrm{Al}_{2} \mathrm{O}_{3}, \mathrm{SLG}$, and $\mathrm{SLG} / \mathrm{Al}_{2} \mathrm{O}_{3}$ ) with a single SLG substrate and a CZTSSe absorber.

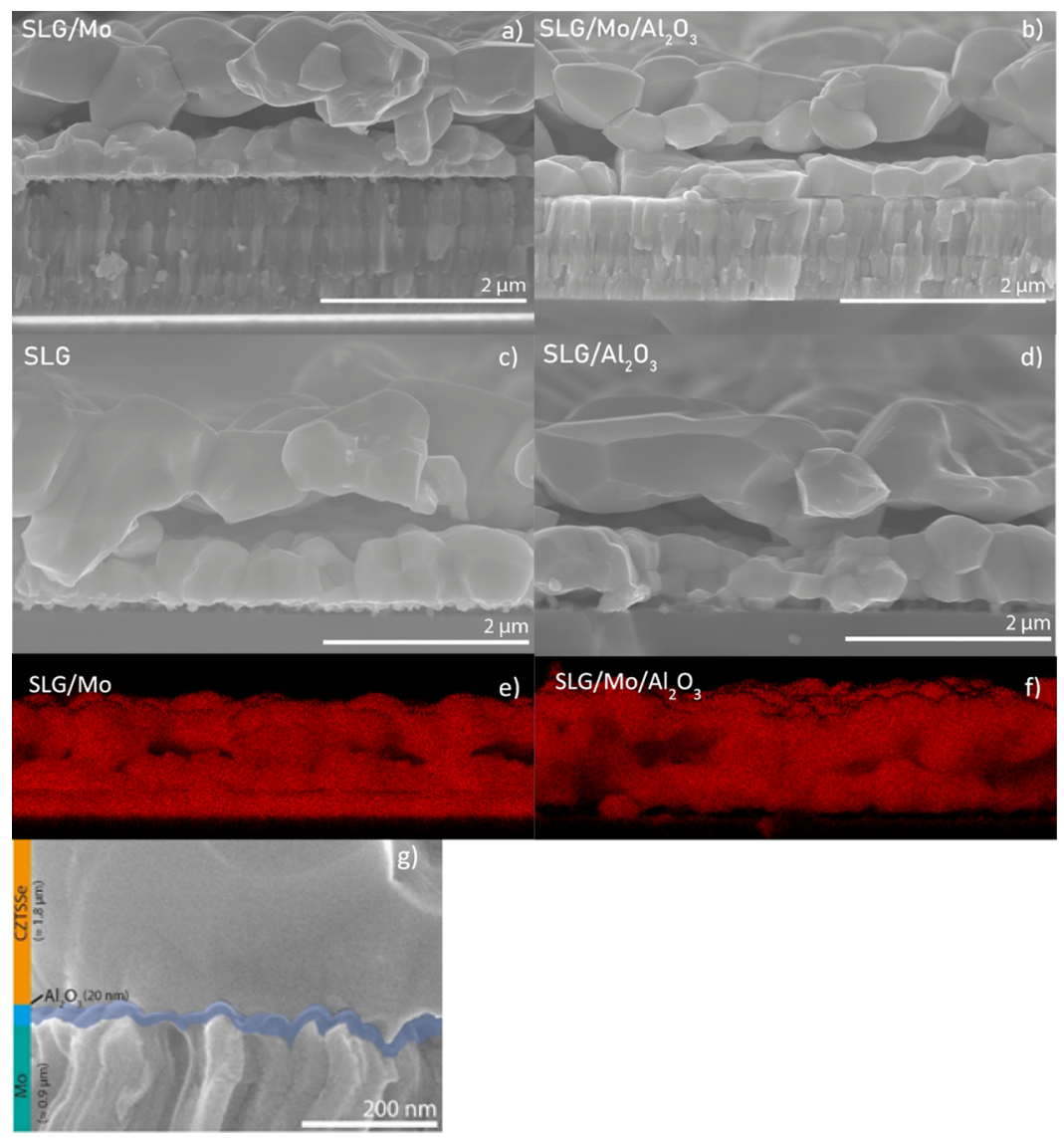

Figure 2. SEM cross-sectional images of the CZTSSe absorber on (a) SLG/Mo, (b) SLG/Mo/ $\mathrm{Al}_{2} \mathrm{O}_{3}$, (c) bare SLG, and (d) SLG/Al $\mathrm{O}_{3}$. (e), (f) SEM-EDS cross-sectional measurements for Se net counts for CZTSSe on SLG/Mo and SLG/Mo/ $\mathrm{Al}_{2} \mathrm{O}_{3}$ structures, respectively. (g) Highresolution SEM cross section of the CZTSSe absorber deposited on $\mathrm{Al}_{2} \mathrm{O}_{3}$ on the Mo side. $\mathrm{Al}_{2} \mathrm{O}_{3}$ is highlighted with the blue color for clarity.

question: is the increase in performance related to the influence of the IL on the $\mathrm{Mo}(\mathrm{S}, \mathrm{Se})_{2}$ growth or on absorber growth dynamics? The question is justified by the additional reported effects (shown in Table 1) the IL has on alkali 
diffusion from the glass substrate, crystallization dynamics, and phase segregation. Further uncertainty is caused by Mo surface roughness. A conformal deposition is necessary to ensure barrier properties against Se diffusion. ${ }^{11}$ These interconnected issues make it challenging to fully understand the origin of the performance improvement and if controlling $\mathrm{Mo}(\mathrm{S}, \mathrm{Se})_{2}$ thickness is beneficial.

In this study, a special sample design was considered to preserve the composition and annealing conditions of the absorber while allowing the comparison of four rear structures (Figure 1). The sample preparation can be divided into the following steps:

1 laser scribing of the Mo layer into $5 \mathrm{~mm}$ wide lines;

2 deposition of a conformal $20 \mathrm{~nm}$ thick $\mathrm{Al}_{2} \mathrm{O}_{3}$ layer by atomic layer deposition (ALD) on half of the scribed Mo layer and the other half was covered to keep it $\mathrm{Al}_{2} \mathrm{O}_{3}$ free;

3 spin-coating of a Na-doped CZTS precursor solution;

4 annealing in a rapid thermal processing (RTP) oven in a Se-rich atmosphere at temperatures up to $550{ }^{\circ} \mathrm{C}$. We used the three-stage annealing profile process developed by Haass et al., ${ }^{19}$ with which a device efficiency of up to $11 \%$ can be achieved.

The as-obtained sample allows for a direct comparison of a single CZTSSe absorber grown on four rear structures: SLG/ $\mathrm{Mo}$, SLG/Mo/ $/ \mathrm{Al}_{2} \mathrm{O}_{3}$, SLG, and SLG $/ \mathrm{Al}_{2} \mathrm{O}_{3}$, corresponding to three different rear interfaces: Mo/CZTSSe, $\mathrm{Al}_{2} \mathrm{O}_{3} / \mathrm{CZTSSe}$, and SLG/CZTSSe.

$\mathrm{Al}_{2} \mathrm{O}_{3}$ was the IL of choice because it reduces surface recombination and increases charge carrier lifetime, thanks to the low defect density at the interface. ${ }^{20}$ The presence of fixed negative charges (corresponding to aluminum vacancies and/ or oxygen interstitials) leads to upward band bending at the absorber interface, which repels the minority charge carriers. $^{21,22}$ This passivation effect is reported to be maximized after annealing treatments. ${ }^{23,24}$

Successful implementation of $\mathrm{Al}_{2} \mathrm{O}_{3}$ as a passivating layer has been reported for $\mathrm{Si}^{23,25} \mathrm{CIGS},{ }^{22,26-28}$ and $\mathrm{CZTS}^{28-31}$ solar cell devices, but in such cases, the $\mathrm{Al}_{2} \mathrm{O}_{3}$ layer is typically patterned or thinner than $5 \mathrm{~nm}$. This allows for carrier collection and absorber adhesion but limits the magnitude of the passivating effect. ${ }^{23}$

This study aims to clarify the influence of an IL at the rear interface on absorber growth and the $V_{\text {oc }}$ of a single absorber. According to the literature, ${ }^{23}$ the thickness of $20 \mathrm{~nm}$ of the $\mathrm{Al}_{2} \mathrm{O}_{3}$ layer and the annealing temperatures up to $550{ }^{\circ} \mathrm{C}$ should provide the best passivation properties. The effectiveness of the passivation is investigated by extracting the nonradiative recombination losses $\left(\Delta V_{\mathrm{oc}, \mathrm{nrad}}\right)$ from quantitative photoluminescence $(\mathrm{PL})$ measurements.

\section{RESULTS AND DISCUSSION}

2.1. Morphology and Crystallinity. Figure 2 presents the SEM cross sections of the absorber on the four rear structures ( $\mathrm{SLG} / \mathrm{Mo}, \mathrm{SLG} / \mathrm{Mo} / \mathrm{Al}_{2} \mathrm{O}_{3}, \mathrm{SLG}$, and $\mathrm{SLG} / \mathrm{Al}_{2} \mathrm{O}_{3}$ ). There is no noticeable difference in morphology or thickness (about $1.7-2 \mu \mathrm{m}$ ) among the cross sections, indicating that the growth dynamics of the absorber layer was comparable. The bare Mo layer reached a thickness of about $1.3 \mu \mathrm{m}$ after selenization due to $\mathrm{Mo}(\mathrm{S}, \mathrm{Se})_{2}$ formation. The Mo layer with $\mathrm{Al}_{2} \mathrm{O}_{3}$ on top measures about $0.9 \mu \mathrm{m}$ (same as the as-deposited Mo layer), indicating that $\mathrm{Al}_{2} \mathrm{O}_{3}$ is an effective barrier for $\mathrm{Se}$ diffusion and that it withstands the annealing conditions. Figure $2 \mathrm{~g}$ shows a high-resolution SEM cross section of the compact $\mathrm{Al}_{2} \mathrm{O}_{3}$ layer sandwiched between a CZTSSe grain and the Mo layer.

X-ray diffraction (XRD) measurements were carried out with a pinhole of $0.5 \mathrm{~mm}$ in diameter attached to the primary beam to assess whether the rear structure affects the absorber crystallinity. Such a configuration allows focusing the X-ray beam on specific locations of the sample. Figure 3a shows the

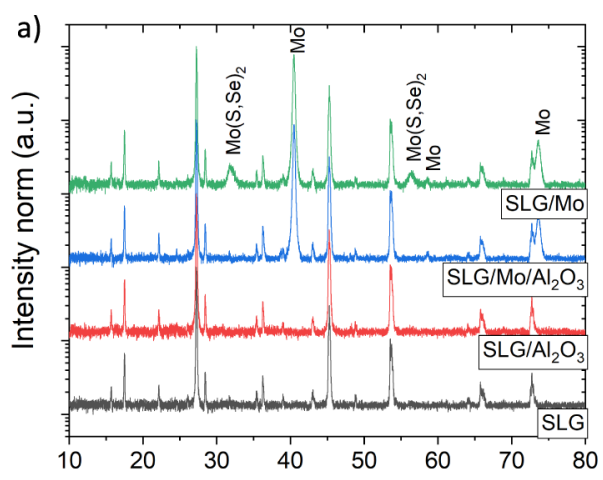

b) $2 \theta$
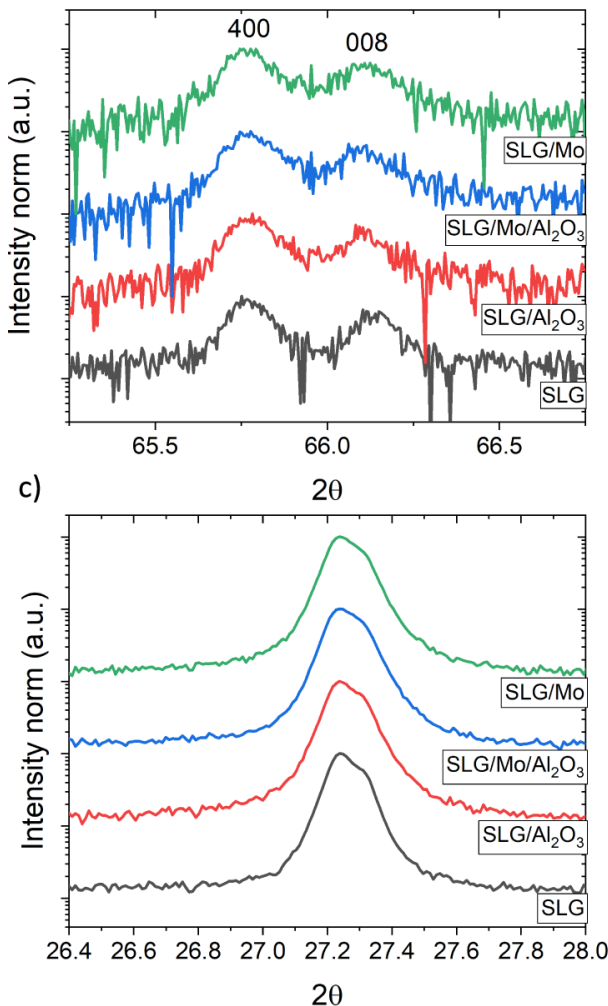

Figure 3. XRD patterns for the CZTSSe absorber grown on four different rear structures. (a) Full XRD pattern $\left(10^{\circ}<2 \theta<80^{\circ}\right)$. (b) High-resolution XRD pattern $\left(65^{\circ}<2 \theta<67^{\circ}\right)$ after stripping the K $\alpha 2$ signal. (c) Zoomed 112 Bragg reflex.

full XRD pattern $\left(10^{\circ}<2 \theta<80^{\circ}\right)$ measured on four sample areas, each corresponding to a different rear structure. Bragg reflexes at $17.47^{\circ}, 27.23^{\circ}$, and $45.25^{\circ}$ confirm the CZTSSe phase. $^{32} \mathrm{Mo}(\mathrm{S}, \mathrm{Se})_{2}$ diffraction peaks $\left(31.76^{\circ}\right.$ and $\left.56.32^{\circ}\right)$ appear only for the side with bare Mo. Thus, $\mathrm{Mo}(\mathrm{S}, \mathrm{Se})_{2}$ is absent or too thin to be measured for the $\mathrm{Mo} / \mathrm{Al}_{2} \mathrm{O}_{3}$ structure. This result is further confirmed through scanning electron 

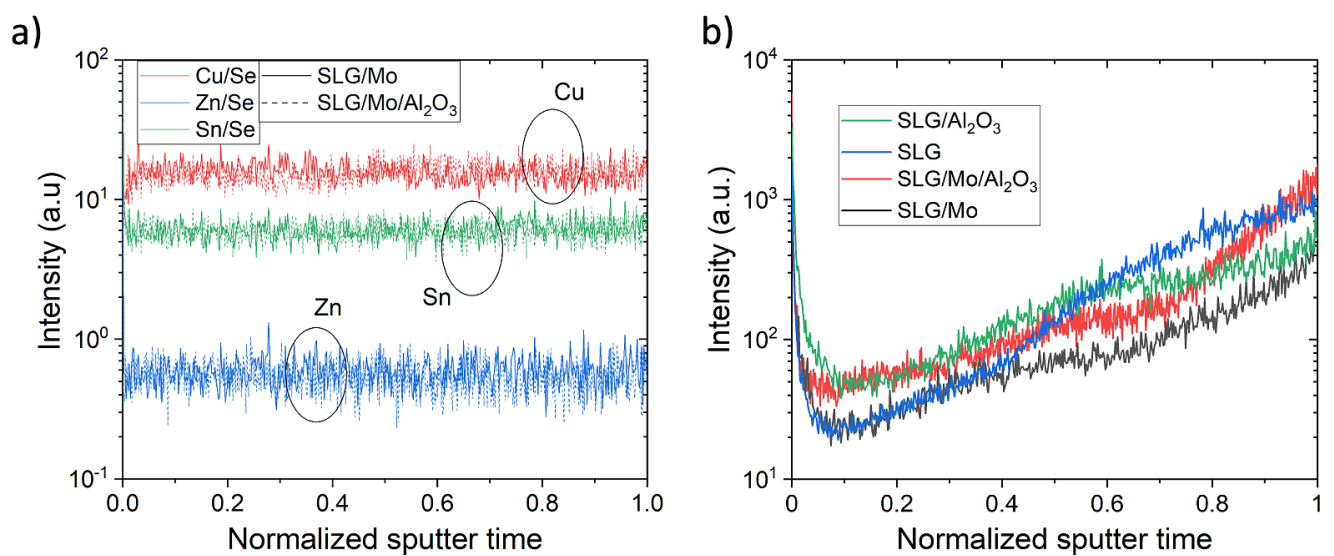

Figure 4. Normalized TOF-SIMS depth profiles of (a) $\mathrm{Cu}, \mathrm{Zn}$, and $\mathrm{Sn}$ for CZTSSe and SLG/Mo and SLG/Mo/ $\mathrm{Al}_{2} \mathrm{O}_{3}$. (b) Comparison of normalized $\mathrm{Na}$ depth profiles for the CZTSSe absorber on the four structures SLG/Mo, SLG/Mo/ $\mathrm{Al}_{2} \mathrm{O}_{3}, \mathrm{SLG}$, and $\mathrm{SLG} / \mathrm{Al}_{2} \mathrm{O}_{3}$.

microscopy and energy dispersive X-ray spectroscopy (SEMEDS) Se maps of the cross sections for SLG/Mo/CZTSSe and $\mathrm{SLG} / \mathrm{Mo} / \mathrm{Al}_{2} \mathrm{O}_{3} / \mathrm{CZTSSe}$ structures (Figure 2e,f, respectively), where a Se-rich layer is visible beneath the CZTSSe absorber only for the SLG/Mo/CZTSSe structure. The 400008 Bragg kesterite diffractions (Figure 3b), which represent lattice parameters $a$ and $c$, respectively, are aligned among the four measurements, indicating a similar order/disorder of the $\mathrm{Cu} / \mathrm{Zn}$ sublattice. ${ }^{33,34}$ The primary 112 Bragg kesterite diffraction is positioned at $27.23^{\circ}$ (Figure 3c) for each part of the absorber and indicates a $\mathrm{S} /(\mathrm{S}+\mathrm{Se})$ ratio of about $5 \%$, as calculated with Vegard's law. ${ }^{35}$ Additional microprobe analysis of an absorber with a comparable composition measured a $\mathrm{S}$ content of 2.7 at. \% and Se of 48.1 at.\%, which corresponds to a $\mathrm{S} /(\mathrm{S}+\mathrm{Se})$ ratio of $5 \%$. The full width at half-maximum (FWHM) for the 112 diffraction peak among the three rear structures ( $\mathrm{SLG} / \mathrm{Mo}, \mathrm{SLG} / \mathrm{Mo} / \mathrm{Al}_{2} \mathrm{O}_{3}$, and $\mathrm{SLG} / \mathrm{Al}_{2} \mathrm{O}_{3}$ ) is $0.137 \pm 0.003$, whereas for bare glass, it is $0.127 \pm 0.003$. For other samples with the same composition, we measured the FWHM in the range of $0.194-0.247$ and did not see any correlation with the rear structure. Therefore, the small difference measured for the sample in this manuscript is insignificant and within statistical error. Eventually, no secondary phases can be identified, although the presence of $\mathrm{Zn}(\mathrm{S}, \mathrm{Se})$ and $\mathrm{Cu}_{2} \mathrm{Sn}(\mathrm{S}, \mathrm{Se})_{3}$ impurity phases cannot be excluded since their Bragg reflexes coincide with those of CZTSSe and therefore cannot be distinguished by XRD. ${ }^{36}$

2.2. Composition. Time-of-flight secondary ion mass spectrometry (TOF-SIMS) allows investigating the elemental depth profiles qualitatively. In Figure 4, both the signal intensity of the matrix elements $(\mathrm{Cu}, \mathrm{Zn}$, and $\mathrm{Sn}$ ) and the sputtering time are normalized, the first by the Se signal intensity and the latter by the absorber depth. The reported profile comparison between CZTSSe on SLG/Mo and SLG/ $\mathrm{Mo} / \mathrm{Al}_{2} \mathrm{O}_{3}$ structures is representative of all the measurements. The flat profiles of the matrix elements $\mathrm{Cu}, \mathrm{Zn}$, and $\mathrm{Sn}$ indicate that the presence or absence of $\mathrm{Mo}$ and/or $\mathrm{Al}_{2} \mathrm{O}_{3}$ does not influence the composition of the absorber throughout its thickness. The result is confirmed by EDS maps (Figure S5), where matrix elements $(\mathrm{Cu}, \mathrm{Zn}$, and $\mathrm{Sn})$ are homogeneously distributed within the absorber thickness. The depth profile in Figure S4 for the CZTSSe absorber on the rear structure SLG/ $\mathrm{Mo} / \mathrm{Al}_{2} \mathrm{O}_{3}$ reveals the $\mathrm{Al}$ signal in the expected area between $\mathrm{Mo}$ and the absorber. One cannot rule out the presence of an unintentional $\mathrm{Al}$ doping in the CZTSSe absorber beyond the resolution of the SIMS measurement; however, small amounts of $\mathrm{Al}$ should not be harmful, but rather beneficial to electrical properties. $^{37}$ As indicated in Table 1 , the addition of an IL can influence alkali-metal diffusion, with $\mathrm{Na}$ playing a significant role in affecting morphological and electrical characteristics of kesterite absorbers. ${ }^{38-40}$ In this study, an $\mathrm{SiO}_{x}$ alkali barrier was sputtered before Mo deposition. This does not entirely block the Na out-diffusion from the SLG substrate but allows to control it. External $\mathrm{Na}$ doping is employed, in the form of $\mathrm{NaCl}$ added to the kesterite precursor solution, to provide a homogeneous $\mathrm{Na}$ source. A stronger $\mathrm{Na}$ signal at the absorber interfaces (Figure 4b) is expected and already observed in other studies. The signal peak at the front might be explained by $\mathrm{Na}$ evaporation from the SLG during the annealing and its subsequent condensation on the front surface of the absorber. In contrast, an increase in $\mathrm{Na}$ intensity toward the back of the absorber is due to $\mathrm{Na}$ diffusion from the SLG. ${ }^{38,41,42}$ No systematic difference in the $\mathrm{Na}$ shape profile correlated with the rear structure can be observed. As measured by EDS, the $\mathrm{Na}$ concentration amounts to about $1 \pm 0.4$ at.\% for each part of the sample (Figure S2d), thus confirming conclusions from TOF-SIMS measurements of a comparable $\mathrm{Na}$ concentration in the bulk of the absorber layer.

X-ray photoelectron spectroscopy (XPS) measurements were carried out to investigate chemical modifications of the surface (Figure S1). As observed in other studies, a thin oxide layer forms on the surface due to exposure to an ambient atmosphere, while the matrix elements exhibit similar depth profiles. $^{43}$

A qualitative assessment of the metal ratios for the absorber bulk was obtained through X-ray fluorescence (XRF) mapping, which allows for detecting changes at a finer resolution than TOF-SIMS. In Figure 5, a correlation of $\mathrm{Zn} / \mathrm{Sn}$ and $\mathrm{Cu} / \mathrm{Sn}$
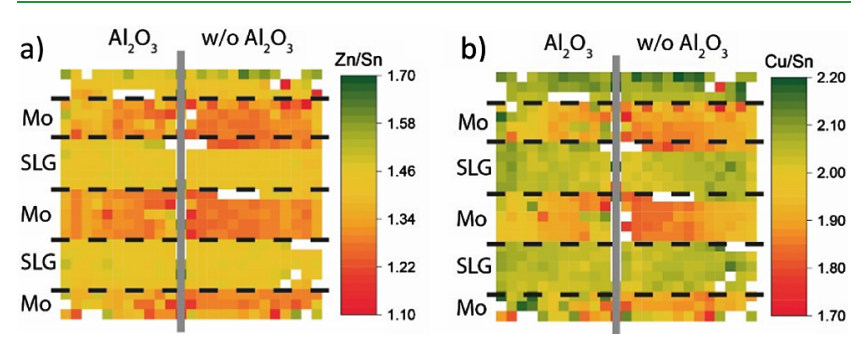

Figure 5. (a) $\mathrm{Zn} / \mathrm{Sn}$ and (b) $\mathrm{Cu} / \mathrm{Sn} \mathrm{XRF}$ metal ratio maps. 
a) PLQY

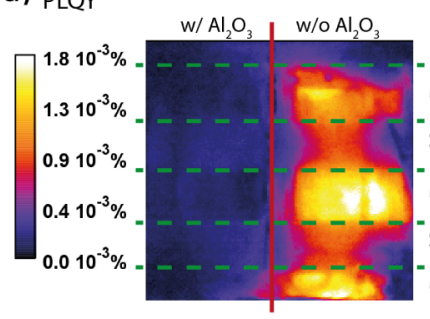

b)

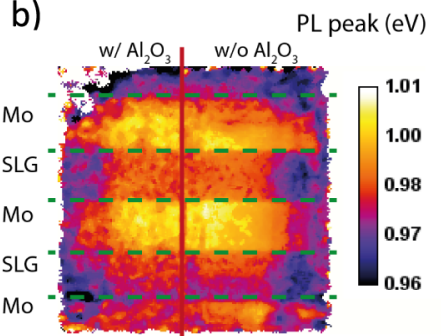

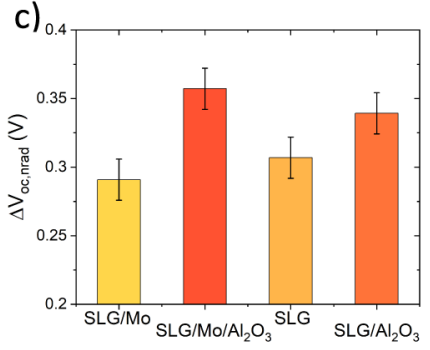

Figure 6. (a) Map of the PLQY. (b) Map of the PL peak position. (c) Conversion of PLQY intensity in nonradiative losses $\left(\Delta V_{\text {oc,nrad }}\right)$.

metal ratios in the presence or absence of the Mo layer can be observed. In contrast, the presence of $\mathrm{Al}_{2} \mathrm{O}_{3}$ does not cause any noticeable influence on the composition. Areas without $\mathrm{Mo}$ have a $\mathrm{Zn}$-richer and $\mathrm{Sn}$-poorer composition compared to the areas with Mo. The heat reflection from metals like Mo can lead to lower temperatures during annealing than the areas without Mo, leading to increased reevaporation of $\mathrm{Sn}$ in the latter ones. The XRF fitting reliability was assessed by comparing the results with SEM-EDS measurements of a similarly processed sample (see Figure S2).

The material characterization presented so far demonstrates that the absorber growth was equivalent concerning morphology and the $\mathrm{Na}$ content comparable among the four sample areas corresponding to the four rear structures. Small variations in metal ratios were detected between $\mathrm{Mo}$ and Mo-free areas, whereas the ratios were identical for $\mathrm{Al}_{2} \mathrm{O}_{3}$ - and $\mathrm{Al}_{2} \mathrm{O}_{3}$-free areas.

2.3. Nonradiative Recombination Losses $\left(\Delta V_{\text {oc,nrad }}\right)$. 2.3.1. PL from the Front of the Absorber. Quantitative PL (also known as absolute PL or photoluminescence quantum yield, PLQY) allows calculating the nonradiative voltage losses following the formula $\Delta V_{\text {oc, nrad }}=-k T \ln (\mathrm{PLQY}){ }^{44}$ where PLQY is the measured calibrated PL intensity. The PLQY measurement was carried out with an excitation laser wavelength of $660 \mathrm{~nm}$.

A color-coded PL image is presented in Figure 6a, where brighter areas imply a stronger PLQY intensity, thus reduced nonradiative voltage losses compared to the darker areas. Nonradiative voltage loss $\left(\Delta V_{\text {oc,nrad }}\right)$ values are presented in Figure $6 \mathrm{c}$. Figure $6 \mathrm{~b}$ shows a color-coded map for the PL peak position, where color brightness is proportional to the PL peak.

Starting with the side without $\mathrm{Al}_{2} \mathrm{O}_{3}$ (right side of the sample in Figure 6a), one can compare CZTSSe grown on SLG and SLG/Mo. The kesterite grown on Mo has a brighter PLQY signal amounting to nonradiative voltage losses of about $290 \mathrm{mV}$, roughly 10-15 mV lower than on SLG. For reference, comparable losses were measured for Li-doped CZTSSe solar cell devices delivering an efficiency higher than $10 \%{ }^{2}$ The PL peak position shifts comparably to the $\Delta V_{\text {oc,nrad }}$ difference between areas with or without Mo (Figure 6b). The PL emission of CZTSSe grown on Mo peaks at roughly $1 \mathrm{eV}$, about 10-15 meV higher than CZTSSe on areas without Mo. The peak shift agrees with the $\mathrm{Sn}$ content variation observed with XRF measurements in Figure 5, as similarly reported in previous studies. ${ }^{45,46}$ By comparison, such a $V_{\mathrm{oc}}$ variation is within the experimental statistical error for the solutionprocessed kesterite in our laboratory.

However, the side with $\mathrm{Al}_{2} \mathrm{O}_{3}$ (left side of the sample) has the highest $\Delta V_{\text {oc,nrad }}$ losses of the sample, which amount to about $350 \mathrm{mV}$, regardless of the presence or absence of Mo beneath $\mathrm{Al}_{2} \mathrm{O}_{3}$. The result is surprising for two main reasons: the influence of the rear structures (SLG or SLG/ $\mathrm{Al}_{2} \mathrm{O}_{3}$ ) and interface $\left(\mathrm{Al}_{2} \mathrm{O}_{3} / \mathrm{CZTSSe}\right)$ on the PL measured from the front should not be so pronounced for an absorber with a thickness of about $2 \mu \mathrm{m}$. Simulations of the PL intensity in function of the recombination velocity at the rear interface were carried out with a solar cell capacitance simulator (SCAPS) (see Figure 7) to evaluate the extent to which the rear interface can

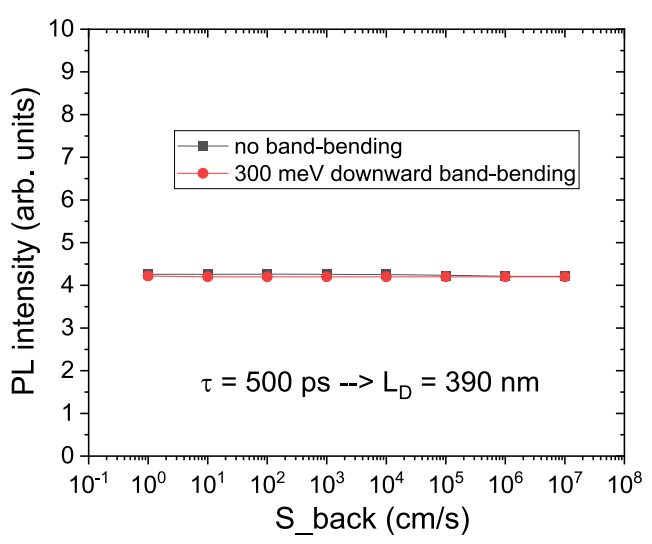

Figure 7. SCAPS simulation of the PL intensity in function of the recombination velocity at the back interface in the case of no band bending at the back and a downward band bending of $300 \mathrm{meV}$.

influence the PL measurement from the front surface. We used the following set of parameters to model the absorber: an absorber thickness of $2 \mu \mathrm{m}$, band gap of $1 \mathrm{eV}$, minority charge mobility $\mu=120 \mathrm{~cm}^{2} / \mathrm{V},{ }^{47}$ and a lifetime $\tau=500 \mathrm{ps},{ }^{48}$ which leads to a diffusion length of the minority charge carrier $L_{\mathrm{D}}<$ $0.5 \mu \mathrm{m}$ based on the formula $L_{\mathrm{D}}=\left(\tau \mu k_{\mathrm{B}} T / q\right)^{0.5}$. Considering the surprising negative effect of the $\mathrm{Al}_{2} \mathrm{O}_{3}$ layer on $\mathrm{PL}$, two hypothetical worst-case scenarios where the bands are not bending upward as expected were examined: one where $\mathrm{Al}_{2} \mathrm{O}_{3}$ does not create any band bending and the other with an arbitrary $300 \mathrm{meV}$ downward band bending at the back. It can be observed that the PL intensity does not depend on the recombination velocity at the rear interface for both scenarios.

There is no measurable difference in composition and $\mathrm{Na}$ distribution between the CZTSSe absorber grown on $\mathrm{Al}_{2} \mathrm{O}_{3}$ (left side) and the one grown without (right side), which could justify the increased nonradiative losses. The result indicates that the presence of the $\mathrm{Al}_{2} \mathrm{O}_{3} \mathrm{IL}$ must have additional effects that were not considered and cannot be assessed within the resolution of the absorber characterization techniques.

2.3.2. PL from the Back of the Absorber. The transparency of the SLG substrate allows carrying out PLQY measurements on the back of the sample on areas where Mo is not present. In 
this manner, the passivation of $\mathrm{Al}_{2} \mathrm{O}_{3}$ is directly assessed through the PL signal intensity. In this case, the analysis will be qualitative and the $\Delta V_{\text {oc,nrad }}$ will not be extracted since the system for the PLQY measurement is not calibrated for recording photon emissions through a layer of glass.

Figure 8 shows the PL map recorded from the back of the sample. It can be noticed that in this case, the intensity of the

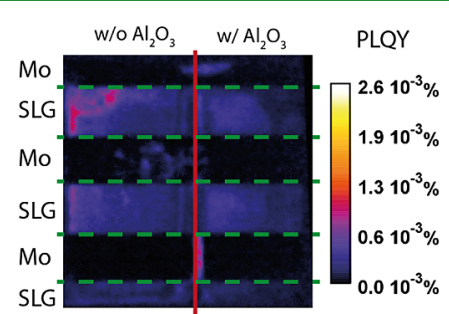

Figure 8. Map of the PLQY, as recorded through the SLG substrate.

PL between CZTSSe on SLG and SLG/ $\mathrm{Al}_{2} \mathrm{O}_{3}$ rear structures is comparable. It follows that the presence of $\mathrm{Al}_{2} \mathrm{O}_{3}$ is not contributing to reducing the nonradiative recombination.

Considering the cross sections presented in Figure 1, one might suggest that the grainy morphology hinders the passivation or limits the absorption of the material. To rule out this factor, a Li-doped CZTSSe absorber displaying a compact morphology with large grains was considered (see Figure 3a for the cross section) and compared with the Nadoped absorber. The PL intensity measured from the back (Figure S3c) is of the same order of magnitude between the two samples. Thus, we can conclude that the morphological compactness did not influence the PL intensity or the contact quality with the $\mathrm{Al}_{2} \mathrm{O}_{3}$ layer.

2.4. Investigation of the $\mathrm{Al}_{2} \mathrm{O}_{3}$ Layer in an MOS Structure. To further understand the lacking passivation effect of the $\mathrm{Al}_{2} \mathrm{O}_{3}$, a metal-oxide semiconductor (MOS) structure, where the layer structure is $\mathrm{SLG} / \mathrm{Mo} / \mathrm{CZTSSe}$ /
$\mathrm{Al}_{2} \mathrm{O}_{3}$ with e-beam evaporated $\mathrm{Ni}-\mathrm{Al}$ contacts, was fabricated (schematic in Figure 9a). This type of device structure allows for a qualitative investigation of the $\mathrm{CZTSSe} / \mathrm{Al}_{2} \mathrm{O}_{3}$ interface by capacitance-voltage (CV) measurements. Two MOS samples were prepared: one was measured after the $\mathrm{Al}_{2} \mathrm{O}_{3}$ deposition $(\mathrm{AD}=$ as deposited $)$. The other was heated on a hot plate at $350{ }^{\circ} \mathrm{C}$ in air for $5 \mathrm{~min}$ after $\mathrm{Al}_{2} \mathrm{O}_{3}$ deposition ( $\mathrm{PDA}=$ postdeposition annealing). The PDA is carried out at a temperature that is as close as possible to the annealing temperature used to crystallize CZTSSe absorbers, ${ }^{49}$ so as to mimic its effect on the CZTSSe $/ \mathrm{Al}_{2} \mathrm{O}_{3}$ interface, while avoiding absorber decomposition. ${ }^{50,51}$

For both devices, the capacitance was measured in forward and reverse bias in a voltage range of -2 to $2 \mathrm{~V}$ at $1 \mathrm{kHz}$ (Figure 9b). Larger voltages caused the breakdown of the dielectric $\left(\mathrm{Al}_{2} \mathrm{O}_{3}\right)$. The capacitance drops at a negative voltage for the $\mathrm{AD}$ device, indicating a negative flat band voltage. This correlates with the presence of net positive fixed charges in the $\mathrm{Al}_{2} \mathrm{O}_{3}$ layer; thus, the $\mathrm{Al}_{2} \mathrm{O}_{3}$ layer in the $\mathrm{AD}$ device is oxygendeficient or aluminum-rich. ${ }^{22}$ It would follow a downward band bending at the interface with the CZTSSe absorber, contrary to what is required for repelling the minority charge carriers. Kotipalli et al. ${ }^{24}$ observed a similar behavior for the same type of device structure but with a CIGS absorber. The negative net fixed charges were recovered after an annealing procedure in a Se-rich atmosphere at $T>500{ }^{\circ} \mathrm{C}$. At such a temperature, kesterite absorbers decompose; ${ }^{52}$ thus, a similar annealing procedure was not considered for this study.

For the PDA device, no capacitance drop can be measured within the voltage range of the analysis. This entails that the fixed charges in the $\mathrm{Al}_{2} \mathrm{O}_{3}$ layer are neutralized or that their influence cannot be measured within the chosen voltage range. For a qualitative assessment of the charge profile, TOF-SIMS measurements were performed on the two MOS devices (Figure 9c). A significant influence can be observed for the oxygen profile throughout the $\mathrm{Al}_{2} \mathrm{O}_{3}$ layer depth. The PDA device presents a noticeably lower intensity for $\mathrm{O}^{-}$ions, while

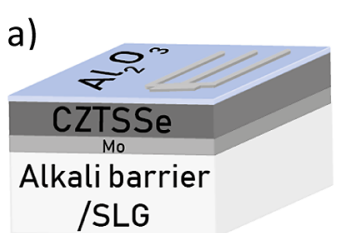

b)

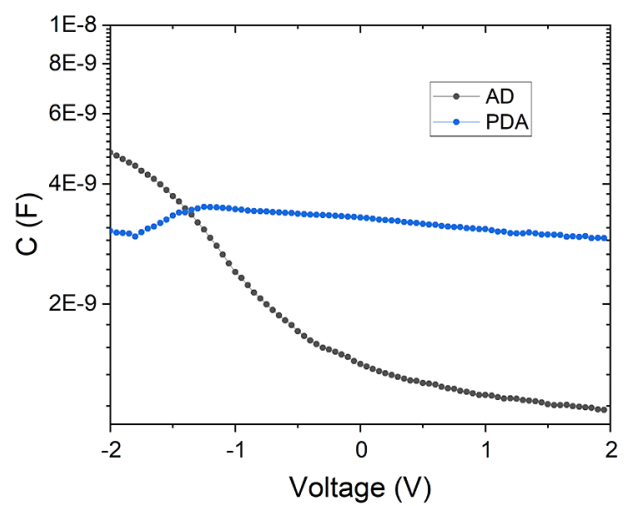

c)

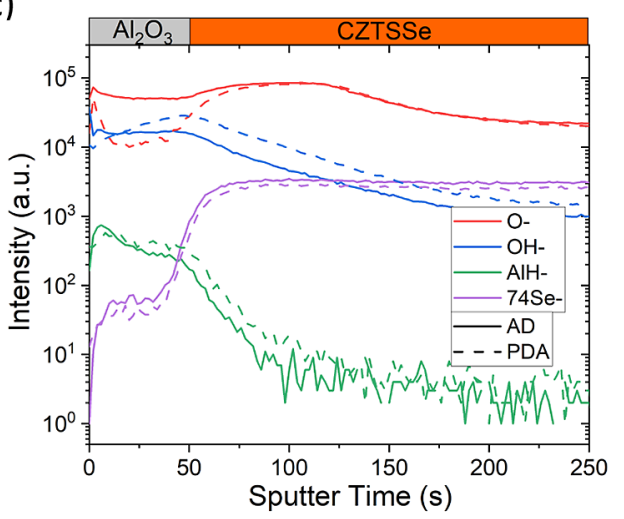

Figure 9. (a) Schematic of the MOS structure SLG/Mo/CZTSSe $/ \mathrm{Al}_{2} \mathrm{O}_{3}$. (b) CV measurement at room-temperature of MOS devices with the $\mathrm{Al}_{2} \mathrm{O}_{3}$ as-deposited $(\mathrm{AD})$ on Mo and after heating on a hotplate (PDA). (c) TOF-SIMS measurements of MOS devices for negative ions. 
the intensity for the $\mathrm{OH}^{-}$ions increases correspondingly. This suggests hydrogen passivation of the dangling oxygen bonds, further reducing the amount of negative charges. ${ }^{53}$ Therefore, we can conclude that high-temperature annealing changes $\mathrm{Al}_{2} \mathrm{O}_{3}$ composition, hence the amount of static charges, which shifts the flat band voltage to more negative values than $-2 \mathrm{~V}$. Eventually, this results in a lack of passivation at the CZTSSe interface, as is observed with the PL measurements in Figure $8 .^{21}$

Our experiment was carried out on a kesterite absorber that was prepared with a two-stepmethod using a solutionprocessed precursor. There are many other methods for preparing the precursor including evaporation, sputtering, and spray-coating among others. As all of these approaches require a high-temperature crystallization step, we believe that our results are valid for kesterite absorbers obtained with the twostep method. ${ }^{49}$ The effect, however, can also be dependent on the thickness of the $\mathrm{Al}_{2} \mathrm{O}_{3}$.

\section{CONCLUSIONS}

In this study, a single absorber was grown on four rear structures ( $\mathrm{SLG} / \mathrm{Mo}, \mathrm{SLG} / \mathrm{Mo} / \mathrm{Al}_{2} \mathrm{O}_{3}$, SLG, and SLG/ $/ \mathrm{Al}_{2} \mathrm{O}_{3}$ ), allowing the testing of the influence of the rear interfaces and presence of Mo on the absorber composition and nonradiative voltage losses, as extracted from the PLQY. Small variations in the composition could be observed between areas with or without the Mo layer, but not with the $\mathrm{Al}_{2} \mathrm{O}_{3} \mathrm{IL}$, while the $\mathrm{Na}$ distribution and quantity in the bulk and on the surface are comparable among all absorber parts.

From PL measurements on both the front and the back interfaces of the absorber, we observed the following:

For front PL: the part of the CZTSSe absorber with $\mathrm{Al}_{2} \mathrm{O}_{3}$ at the back has higher nonradiative losses than the part without it. The cause of the increased losses could not be identified with the resolution of the characterization techniques considered in the present study.

For back PL measured through the SLG substrate: the $\mathrm{Al}_{2} \mathrm{O}_{3}$ layer does not provide a measurable passivation effect. This can be explained by a net amount of positive fixed charges in the $\mathrm{Al}_{2} \mathrm{O}_{3}$ layer appearing after the kesterite precursor deposition.

Eventually, this study enabled us to verify that different rear structures can influence the absorber metal ratios, despite an unchanged morphology. While the IL $\mathrm{Al}_{2} \mathrm{O}_{3}$ limits the diffusion of Se to the back and avoids the contact of kesterite with the Mo layer, this does not lead to any positive impact on the $\Delta V_{\text {oc,nrad }}$ of an absorber optimized for a device efficiency $>10 \%$. This is explained by a negative influence of the two-step fabrication procedure necessary for kesterite absorbers on the passivating properties of the $\mathrm{Al}_{2} \mathrm{O}_{3}$ layer. The results further indicate that the Mo back contact represents the best solution for kesterite absorbers, and the reduction in $\Delta V_{\text {oc,nrad }}$ should be addressed by identifying and passivating the detrimental defects present in the kesterite bulk material.

\section{EXPERIMENTAL SECTION}

4.1. Chemicals. The precursor solution consisted of thiourea (99\%+, Sigma-Aldrich), tin chloride dihydrate $\left(\mathrm{SnCl}_{2}{ }_{2} \mathrm{H}_{2} \mathrm{O}, 98 \%\right.$, Sigma-Aldrich), zinc chloride $\left(\mathrm{ZnCl}_{2}, 99.99 \%\right.$, Alfa Aesar), copper chloride dihydrate $\left(\mathrm{CuCl}_{2} \cdot 2 \mathrm{H}_{2} \mathrm{O}, \geq 99.99 \%\right.$, Sigma-Aldrich), and sodium chloride $(\mathrm{NaCl}, 99.99 \%$, Alfa Aesar) dissolved in dimethyl sulfoxide (DMSO, 99.9\%, Alfa Aesar).

4.2. Sample Preparation. A $200-300 \mathrm{~nm}$ thick $\mathrm{SiO}_{x}$ alkali diffusion barrier layer was sputtered onto a $1 \mathrm{~mm}$ thick soda-lime glass
(SLG) with subsequent deposition of about $1 \mu \mathrm{m}$ molybdenum. The molybdenum layer was patterned with a picosecond pulse laser with a wavelength of $1064 \mathrm{~nm}$, power of $750 \mathrm{~mW}$, and frequency of $20 \mathrm{kHz}$. The $\mathrm{Al}_{2} \mathrm{O}_{3}$ layer was deposited with a Fiji G2 ALD system (Veeco Instruments, Inc.). The process was performed at a substrate temperature of $150{ }^{\circ} \mathrm{C}$ with argon as a carrier gas at a base pressure of $25 \mathrm{~Pa}$. The precursors were trimethylaluminum (TMA) (SigmaAldrich) and $\mathrm{H}_{2} \mathrm{O}$. TMA and $\mathrm{H}_{2} \mathrm{O}$ were kept unheated. The growth rate was determined by ellipsometry on $\mathrm{Si}(100)$ reference substrates, and linear growth was observed with a growth rate of $0.99 \AA \cdot \mathrm{cycle}^{-1}$. The precursor solution was spin-coated onto the Mo layer and dried on a hotplate at $320{ }^{\circ} \mathrm{C}$ in air. The spin-coating and drying steps were repeated 12 times to obtain the desired precursor film thickness of about 1.7-2 $\mu \mathrm{m}$. All samples were annealed in an RTP furnace (RTP Annealsys AS ONE 150) inside a closed graphite box with selenium pellets $(800 \mathrm{mg})$. The temperature gradient employed for annealing was the three-stage process holding at 300,500 , and $550{ }^{\circ} \mathrm{C} .{ }^{19}$ After selenization, the absorbers were immersed for $5 \mathrm{~min}$ in a $10 \mathrm{wt} \%$ $(\mathrm{NH})_{4} \mathrm{~S}_{2}$ solution to clean the surface from contaminations and oxides.

4.3. Composition and Morphology. SEM measurements were performed using a Hitachi S-4800 electron microscope. EDS measurements were performed using a Zeiss 1550 SEM with the Oxford AZtec EDS system and an ESEM QuantaFEG650 from FEI (ThermoFisher) with detectors such as ETD (Everhart-Thornley detector) for SE imaging, CBS (concentric-backscattering detector) for BSE imaging, and EDX: ThermoNoran with SDD (Si-drift detector) $60 \mathrm{~mm}^{2}$. XPS measurements were performed using a Quantum2000 photoelectron spectrometer from Physical Electronics with a monochromatic $\mathrm{Al} \mathrm{K}_{\alpha}$ source, operated at a base pressure below $10^{-9}$ mbar. XRF was performed with a Bruker M4 Tornado, using a rhodium tube operated at $20 \mathrm{keV}$ as an X-ray source. A total of 625 data points (spot size $\approx 20 \mu \mathrm{m}$ diameter) were acquired over the sample. The spectra were then evaluated with an SLG/Mo/MoSe $/$ CZTSSe multilayer model (using the Bruker software suite), using elemental metals and chalcogen layers as calibration standards. Depth profile measurements were performed with a TOF-SIMS system from ION-TOF using $\mathrm{O}^{+2}$ primary ions with $2 \mathrm{keV}$ of ion energy, a current of $400 \mathrm{nA}$, and a raster size of $300 \times 300 \mu \mathrm{m}^{2}$. An area of $100 \times 100$ $\mu \mathrm{m}^{2}$ in-depth profiles was analyzed using $\mathrm{Bi}^{+}$ions with $25 \mathrm{keV}$ of ion energy.

Microprobe analysis was carried out with a JXA-8530F JEOL SUPERPROBE, equipped with a field emission electron probe microanalyzer (FE-EPMA) and four crystal spectrometers (WDS) in a $3 \times 3 \mathrm{~mm}^{2}$ square area on the center of the absorber layer.

4.4. Crystallinity. XRD patterns for thin films were recorded in $2 \theta / \theta$ scan mode using a Bruker D8 diffractometer with $\mathrm{Cu} \mathrm{Ko}$ radiation $(\lambda=1.5418 \AA$, beam voltage: $40 \mathrm{kV}$, beam current: $40 \mathrm{~mA}$, calibrated using $\mathrm{Si}(100)$ and $\mathrm{Si}(111)$ single crystals), a step size of $0.05^{\circ}$, and a scan rate of $0.5 \mathrm{~s} \mathrm{step}^{-1}$ for the full pattern and a step size of $0.005^{\circ}$ and a scan rate of $2 \mathrm{~s} \mathrm{step}^{-1}$ for the high-resolution pattern. A pinhole of $0.5 \mathrm{~mm}$ in diameter was attached to the primary beam to limit the measurement area.

4.5. PL. The intensity calibrated PL data have been acquired with a custom setup described elsewhere. ${ }^{54}$ The excitation has been carried out with $660 \mathrm{~nm}$ lasers coupled to homogenizer units. The excitation intensity was equivalent to $>2$ sun $\left(6.1 \times 10^{21}\right.$ photons $\left.\mathrm{m}^{-2} \mathrm{~s}^{-1}\right) .55$ Relative PL measurements were carried out with a laser wavelength of $640 \mathrm{~nm}$ and an intensity equivalent to $1.22 \mathrm{~W} / \mathrm{cm}^{2}$.

4.6. MOS Device Characterization. Room-temperature CV measurements were carried out with an LCR meter from Agilent (E4990A) with an AC voltage of $30 \mathrm{mV}$ at $25^{\circ} \mathrm{C}$.

\section{ASSOCIATED CONTENT}

\section{(s) Supporting Information}

The Supporting Information is available free of charge at https://pubs.acs.org/doi/10.1021/acsami.1c02437.

XPS measurement of the absorber surface (Figure S1); comparison of the metal ratio values between XRF map 
and EDX measurements (Figure S2); SEM cross section and PL measurement of $\mathrm{Li}$ - and $\mathrm{Na}$-doped absorbers deposited on SLG (Figure S3); TOF-SIMS depth profile for the CZTSSe absorber on the rear structure SLG/ $\mathrm{Mo} / \mathrm{Al}_{2} \mathrm{O}_{3}$ (Figure S4); and EDS maps for elements $\mathrm{Cu}$, $\mathrm{Zn}$, and $\mathrm{Sn}$ of CZTSSe absorbers (Figure S5) (PDF)

\section{AUTHOR INFORMATION}

\section{Corresponding Author}

Antonio Cabas-Vidani - Laboratory for Thin Films and Photovoltaics, Empa-Swiss Federal Laboratories for Materials Science and Technology, Dübendorf 8600, Switzerland; () orcid.org/0000-0002-2692-5859;

Email: antonio.cabasvidani@empa.ch

\section{Authors}

Leo Choubrac - Department of Structure and Dynamics of Energy Materials, Helmholtz-Zentrum für Materialien und Energie GmbH, Berlin D-14109, Germany

José A. Márquez - Department of Structure and Dynamics of Energy Materials, Helmholtz-Zentrum für Materialien und Energie GmbH, Berlin D-14109, Germany; (1) orcid.org/ 0000-0002-8173-2566

Thomas Unold - Department of Structure and Dynamics of Energy Materials, Helmholtz-Zentrum für Materialien und Energie GmbH, Berlin D-14109, Germany; (1) orcid.org/ 0000-0002-5750-0693

Matthias Maiberg - Institute of Physics, Martin-LutherUniversity Halle-Wittenberg, Halle 06120, Germany

Roland Scheer - Institute of Physics, Martin-LutherUniversity Halle-Wittenberg, Halle 06120, Germany

$\mathrm{Hu} \mathrm{Li} \mathrm{-} \mathrm{Ångström} \mathrm{Laboratory,} \mathrm{Department} \mathrm{of} \mathrm{Engineering}$ Sciences, Uppsala University, Uppsala 75121, Sweden; School of Microelectronics, Shandong University, Jinan 250100, China

Klaus Leifer - Ångström Laboratory, Department of Engineering Sciences, Uppsala University, Uppsala 75121, Sweden

Robin Pauer - Electron Microscopy Center, Empa-Swiss Federal Laboratories for Materials Science and Technology, Dübendorf 8600, Switzerland

Evgeniia Gilshtein - Laboratory for Thin Films and Photovoltaics, Empa-Swiss Federal Laboratories for Materials Science and Technology, Dübendorf 8600, Switzerland

Ayodhya N. Tiwari - Laboratory for Thin Films and Photovoltaics, Empa-Swiss Federal Laboratories for Materials Science and Technology, Dübendorf 8600, Switzerland

Yaroslav E. Romanyuk - Laboratory for Thin Films and Photovoltaics, Empa-Swiss Federal Laboratories for Materials Science and Technology, Dübendorf 8600, Switzerland

Complete contact information is available at:

https://pubs.acs.org/10.1021/acsami.1c02437

\section{Author Contributions}

The manuscript was written through the contributions of all authors. All authors have approved the final version of the manuscript.

\section{Funding}

H.L. and K.L. received funding from the Svenska Forskningsrådet Formas Foundation. H.L. received funding from the Qilu Young Scholar Program of Shandong University. A.C.-V., L.C., J.A.M., T.U., M.M., R.S., R.P., E.G., A.N.T., and
Y.E.R. received funding from the Horizon2020 Framework Program.

\section{Notes}

The authors declare no competing financial interest.

\section{ACKNOWLEDGMENTS}

The Horizon 2020 program supported this research under the project STARCELL (H2020-NMBP-03-2016-720907). The Formas Foundation (2019-01538) and the Qilu Young Scholar Program of Shandong University are also acknowledged for the financial support. The authors would also like to thank the whole team of the Laboratory for Thin Films and Photovoltaics.

\section{REFERENCES}

(1) Taskesen, T.; Neerken, J.; Schoneberg, J.; Pareek, D.; Steininger, V.; Parisi, J.; Gütay, L. Device Characteristics of an $11.4 \%$ CZTSe Solar Cell Fabricated from Sputtered Precursors. Adv. Energy Mater. 2018, 8, No. 1703295.

(2) Cabas-Vidani, A.; Haass, S. G.; Andres, C.; Caballero, R.; Figi, R.; Schreiner, C.; Márquez, J. A.; Hages, C.; Unold, T.; Bleiner, D.; Tiwari, A. N.; Romanyuk, Y. E. High-Efficiency $\left(\mathrm{Li}_{\mathrm{x}} \mathrm{Cu}_{1-\mathrm{x}}\right)_{2} \mathrm{ZnSn}$ $(\mathrm{S}, \mathrm{Se})_{4}$ Kesterite Solar Cells with Lithium Alloying. Adv. Energy Mater. 2018, 8, No. 1801191.

(3) Son, D.-H.; Kim, S.-H.; Kim, S.-Y.; Kim, Y.-I.; Sim, J.-H.; Park, S.-N.; Jeon, D.-H.; Hwang, D.-K.; Sung, S.-J.; Kang, J.-K.; Yang, K.-J.; Kim, D.-H. Effect of solid- $\mathrm{H}_{2} \mathrm{~S}$ gas reactions on CZTSSe thin film growth and photovoltaic properties of a $12.62 \%$ efficiency device. $J$. Mater. Chem. A 2019, 7, 25279-25289.

(4) Giraldo, S.; Saucedo, E.; Neuschitzer, M.; Oliva, F.; Placidi, M.; Alcobé, X.; Izquierdo-Roca, V.; Kim, S.; Tampo, H.; Shibata, H.; Pérez-Rodríguez, A.; Pistor, P. How Small Amounts of Ge Modify the Formation Pathways and Crystallization of Kesterites. Energy Environ. Sci. 2018, 11, 582.

(5) Wang, W.; Winkler, M. T.; Gunawan, O.; Gokmen, T.; Todorov, T. K.; Zhu, Y.; Mitzi, D. B. Device Characteristics of CZTSSe ThinFilm Solar Cells with $12.6 \%$ Efficiency. Adv. Energy Mater. 2014, 4, 15.

(6) Gong, Y.; Zhang, Y.; Jedlicka, E.; Giridharagopal, R.; Clark, J. A.; Yan, W.; Niu, C.; Qiu, R.; Jiang, J.; Yu, S.; Wu, S.; Hillhouse, H. W.; Ginger, D. S.; Huang, W.; Xin, H. $\mathrm{Sn}^{4+}$ Precursor Enables $12.4 \%$ Efficient Kesterite Solar Cell from DMSO Solution with Open Circuit Voltage Deficit below 0.30 V. Sci. China Mater. 2020, 64, 1-9.

(7) Li, J.; Huang, Y.; Huang, J.; Liang, G.; Zhang, Y.; Rey, G.; Guo, F.; Su, Z.; Zhu, H.; Cai, L.; Sun, K.; Sun, Y.; Liu, F.; Chen, S.; Hao, X.; Mai, Y.; Green, M. A. Defect Control for 12. 5\% Efficiency $\mathrm{Cu}_{2} \mathrm{ZnSnSe}_{4}$ Kesterite Thin-Film Solar Cells by Engineering of Local Chemical Environment. Adv. Mater. 2020, 32, No. 2005268.

(8) Krause, M.; Nikolaeva, A.; Maiberg, M.; Jackson, P.; Hariskos, D.; Witte, W.; Márquez, J. A.; Levcenko, S.; Unold, T.; Scheer, R.; Abou-Ras, D. Microscopic Origins of Performance Losses in Highly Efficient $\mathrm{Cu}(\mathrm{In}, \mathrm{Ga}) \mathrm{Se}_{2}$ Thin-Film Solar Cells. Nat. Commun. 2020, 11, No. 4189.

(9) Scragg, J. J.; Wätjen, J. T.; Edoff, M.; Ericson, T.; Kubart, T.; Platzer-Björkman, C. A Detrimental Reaction at the Molybdenum Back Contact in $\mathrm{Cu}_{2} \mathrm{ZnSn}(\mathrm{S}, \mathrm{Se})_{4}$ Thin-Film Solar Cells. J. Am. Chem. Soc. 2012, 134, 19330-19333.

(10) Platzer-Björkman, C.; Barreau, N.; Bär, M.; Choubrac, L.; Grenet, L.; Heo, J.; Kubart, T.; Mittiga, A.; Sanchez, Y.; Scragg, J.; Sinha, S.; Valentini, M. Back and Front Contacts in Kesterite Solar Cells: State-of-the-Art and Open Questions. J. Phys. Energy 2019, 1, No. 044005.

(11) Englund, S.; Saini, N.; Platzer-Björkman, C. $\mathrm{Cu}_{2} \mathrm{ZnSn}(\mathrm{S}, \mathrm{Se})_{4}$ from Annealing of Compound Co-Sputtered Precursors-Recent Results and Open Questions. Sol. Energy 2018, 175, 84-93.

(12) Park, J.; Huang, J.; Sun, K.; Ouyang, Z.; Liu, F.; Yan, C.; Sun, H.; Pu, A.; Green, M.; Hao, X. The Effect of Thermal Evaporated 
$\mathrm{MoO}_{3}$ Intermediate Layer as Primary Back Contact for Kesterite $\mathrm{Cu}_{2} \mathrm{ZnSnS}_{4}$ Solar Cells. Thin Solid Films 2018, 648, 39-45.

(13) Liu, L.; Lau, T.-K.; Zhi, Z.; Huang, L.; Wang, S.; Xiao, X. Modification of Mo Back Contact with $\mathrm{MoO}_{3-\mathrm{x}}$ Layer and Its Effect to Enhance the Performance of $\mathrm{Cu}_{2} \mathrm{ZnSnS}_{4}$ Solar Cells. Sol. RRL 2018, 2, No. 1800243.

(14) Englund, S.; Grini, S.; Donzel-Gargand, O.; Paneta, V.; Kosyak, V.; Primetzhofer, D.; Scragg, J. J. S.; Platzer-Björkman, C. TiN Interlayers with Varied Thickness in $\mathrm{Cu}_{2} \mathrm{ZnSnS}(\mathrm{e})_{4}$ Thin Film Solar Cells: Effect on Na Diffusion, Back Contact Stability, and Performance. Phys. Status Solidi A 2018, 215, 1-11.

(15) Liu, F.; Huang, J.; Sun, K.; Yan, C.; Shen, Y.; Park, J.; Pu, A.; Zhou, F.; Liu, X.; Stride, J. A.; Green, M. A.; Hao, X. Beyond $8 \%$ Ultrathin Kesterite $\mathrm{Cu}_{2} \mathrm{ZnSnS}_{4}$ Solar Cells by Interface Reaction Route Controlling and Self-Organized Nanopattern at the Back Contact. NPG Asia Mater. 2017, 9, e401-e401.

(16) Liu, F.; Sun, K.; Li, W.; Yan, C.; Cui, H.; Jiang, L.; Hao, X.; Green, M. A. Enhancing the $\mathrm{Cu}_{2} \mathrm{ZnSnS}_{4}$ Solar Cell Efficiency by Back Contact Modification: Inserting a Thin $\mathrm{TiB}_{2}$ Intermediate Layer at $\mathrm{Cu}_{2} \mathrm{ZnSnS}_{4} / \mathrm{Mo}$ Interface. Appl. Phys. Lett. 2014, 104, No. 051105.

(17) López-Marino, S.; Placidi, M.; Pérez-Tomás, A.; Llobet, J.; Izquierdo-Roca, V.; Fontané, X.; Fairbrother, A.; EspíndolaRodríguez, M.; Sylla, D.; Pérez-Rodríguez, A.; Saucedo, E. Inhibiting the Absorber/Mo-Back Contact Decomposition Reaction in $\mathrm{Cu}_{2} \mathrm{ZnSnSe}_{4}$ Solar Cells: The Role of a $\mathrm{ZnO}$ Intermediate Nanolayer. J. Mater. Chem. A 2013, 1, 8338-8343.

(18) Colina, M.; Martin, I.; Giraldo, S.; Sanchez-Gonzalez, Y.; Kondrotas, R.; Oliva, F.; Izquierdo-Roca, V.; Perez-Rodriguez, A.; Coll, A.; Alcubilla, R.; Saucedo, E. Influence of Amorphous Silicon Carbide Intermediate Layer in the Back-Contact Structure of $\mathrm{Cu}_{2} \mathrm{ZnSnSe}_{4}$ Solar Cells. IEEE J. Photovoltaics 2016, 6, 1327-1332.

(19) Haass, S. G.; Diethelm, M.; Werner, M.; Bissig, B.; Romanyuk, Y. E.; Tiwari, A. N. 11.2\% Efficient Solution Processed Kesterite Solar Cell with a Low Voltage Deficit. Adv. Energy Mater. 2015, 5, 1-7.

(20) Hsu, W. W.; Chen, J. Y.; Cheng, T. H.; Lu, S. C.; Ho, W. S.; Chen, Y. Y.; Chien, Y. J.; Liu, C. W. Surface Passivation of $\mathrm{Cu}(\mathrm{In}, \mathrm{Ga}) \mathrm{Se}_{2}$ Using Atomic Layer Deposited $\mathrm{Al}_{2} \mathrm{O}_{3}$. Appl. Phys. Lett. 2012, 100, 1-4.

(21) Weber, J. R.; Janotti, A.; Van De Walle, C. G. Native Defects in $\mathrm{Al}_{2} \mathrm{O}_{3}$ and Their Impact on III-V/ $\mathrm{Al}_{2} \mathrm{O}_{3}$ Metal-Oxide-SemiconductorBased Devices. J. Appl. Phys. 2011, 109, No. 033715.

(22) Joel, J. Characterization of $\mathrm{Al}_{2} \mathrm{O}_{3}$ as CIGS Surface Passivation Layer in High-Efficiency CIGS Solar Cells, Uppsala Universitet, 2014.

(23) Dingemans, G.; Seguin, R.; Engelhart, P.; Van De Sanden, M. C. M.; Kessels, W. M. M. Silicon Surface Passivation by Ultrathin $\mathrm{Al}_{2} \mathrm{O}_{3}$ Films Synthesized by Thermal and Plasma Atomic Layer Deposition. Phys. Status Solidi RRL 2010, 4, 10-12.

(24) Kotipalli, R.; Vermang, B.; Joel, J.; Rajkumar, R.; Edoff, M.; Flandre, D. Investigating the electronic properties of $\mathrm{Al}_{2} \mathrm{O}_{3}$ / $\mathrm{Cu}(\mathrm{In}, \mathrm{Ga}) \mathrm{Se}_{2}$ interface. AIP Adv. 2015, 5, No. 107101.

(25) Dingemans, G.; Beyer, W.; Van De Sanden, M. C. M.; Kessels, W. M. M. Hydrogen Induced Passivation of Si Interfaces by $\mathrm{Al}_{2} \mathrm{O}_{3}$ Films and $\mathrm{SiO}_{2} / \mathrm{Al}_{2} \mathrm{O}_{3}$ Stacks. Appl. Phys. Lett. 2010, 97, 2008-2011.

(26) Joel, J.; Vermang, B.; Larsen, J.; Donzel-Gargand, O.; Edoff, M. On the Assessment of CIGS Surface Passivation by Photoluminescence. Phys. Status Solidi RRL 2015, 9, 288-292.

(27) Keller, J.; Gustavsson, F.; Stolt, L.; Edoff, M.; Törndahl, T. On the Beneficial Effect of $\mathrm{Al}_{2} \mathrm{O}_{3}$ Front Contact Passivation in $\mathrm{Cu}(\mathrm{In}, \mathrm{Ga}) \mathrm{Se}_{2}$ Solar Cells. Sol. Energy Mater. Sol. Cells 2017, 159, $189-196$.

(28) Bissig, B.; Guerra-Nunez, C.; Carron, R.; Nishiwaki, S.; La Mattina, F.; Pianezzi, F.; Losio, P. A.; Avancini, E.; Reinhard, P.; Haass, S. G.; Lingg, M.; Feurer, T.; Utke, I.; Buecheler, S.; Tiwari, A. N. Surface Passivation for Reliable Measurement of Bulk Electronic Properties of Heterojunction Devices. Small 2016, 12, 5339-5346.

(29) Cui, X.; Sun, K.; Huang, J.; Lee, C. Y.; Yan, C.; Sun, H.; Zhang, Y.; Liu, F.; Hossain, M. A.; Zakaria, Y.; Wong, L. H.; Green, M.; Hoex, B.; Hao, X. Enhanced Heterojunction Interface Quality to Achieve 9.3\% Efficient Cd-Free $\mathrm{Cu}_{2} \mathrm{ZnSnS}_{4}$ Solar Cells Using Atomic
Layer Deposition ZnSnO Buffer Layer. Chem. Mater. 2018, 30, 78607871.

(30) Park, J.; Huang, J.; Yun, J.; Liu, F.; Ouyang, Z.; Sun, H.; Yan, C.; Sun, K.; Kim, K.; Seidel, J.; Chen, S.; Green, M. A.; Hao, X. The Role of Hydrogen from ALD- $\mathrm{Al}_{2} \mathrm{O}_{3}$ in Kesterite $\mathrm{Cu}_{2} \mathrm{ZnSnS}$ Solar Cells: Grain Surface Passivation. Adv. Energy Mater. 2018, 8, 3-9.

(31) Lee, Y. S.; Gershon, T.; Todorov, T. K.; Wang, W.; Winkler, M. T.; Hopstaken, M.; Gunawan, O.; Kim, J. Atomic Layer Deposited Aluminum Oxide for Interface Passivation of $\mathrm{Cu}_{2} \mathrm{ZnSn}(\mathrm{S}, \mathrm{Se})_{4}$ ThinFilm Solar Cells. Adv. Energy Mater. 2016, 6, 2-6.

(32) Nateprov, A.; Kravtsov, V. C.; Gurieva, G.; Schorr, S. Single Crystal X Ray Structure Investigation of Cu2ZnSnSe4. Surf. Eng. Appl. Electrochem. 2013, 49, 423-426.

(33) Choubrac, L.; Paris, M.; Lafond, A.; Guillot-Deudon, C.; Rocquefelte, X.; Jobic, S. Multinuclear (67Zn, $119 \mathrm{Sn}$ and $65 \mathrm{Cu}$ ) NMR Spectroscopy-An Ideal Technique to Probe the Cationic Ordering in $\mathrm{Cu}_{2} \mathrm{ZnSnS}_{4}$ Photovoltaic Materials. Phys. Chem. Chem. Phys. 2013, 15, 10722-10725.

(34) Márquez, J.; Neuschitzer, M.; Dimitrievska, M.; Gunder, R.; Haass, S.; Werner, M.; Romanyuk, Y. E.; Schorr, S.; Pearsall, N. M.; Forbes, I. Systematic Compositional Changes and Their Influence on Lattice and Optoelectronic Properties of $\mathrm{Cu}_{2} \mathrm{ZnSnSe}_{4}$ Kesterite Solar Cells. Sol. Energy Mater. Sol. Cells 2016, 144, 579-585.

(35) Denton, A. R.; Ashcroft, N. W. Vegard's Law. Phys. Rev. A 1991, 43, 3161-3164.

(36) Dale, P. J.; Hoenes, K.; Scragg, J.; Siebentritt, S. A. Review of the Challenges Facing Kesterite Based Thin Film Solar Cells. Conf. Rec. IEEE Photovoltaic Spec. Conf. 2009, 002080-002085.

(37) Kuo, D. H.; Tsega, M. Hole Mobility Enhancement of CuDeficient $\mathrm{Cu}_{1.75} \mathrm{Zn}\left(\mathrm{Sn}_{1-\mathrm{x}} \mathrm{Al}_{\mathrm{x}}\right) \mathrm{Se}_{4}$ Bulks. J. Solid State Chem. 2013, 206, 134-138.

(38) Abzieher, T.; Schnabel, T.; Hetterich, M.; Powalla, M.; Ahlswede, E.; Kesterite, I. Source and Effects of Sodium in Solution-Processed Kesterite Solar Cells. Phys. Status Solidi A 2016, 213, 1039-1049.

(39) Gershon, T.; Shin, B.; Bojarczuk, N.; Hopstaken, M.; Mitzi, D. B.; Guha, S. The Role of Sodium as a Surfactant and Suppressor of Non-Radiative Recombination at Internal Surfaces in $\mathrm{Cu}_{2} \mathrm{ZnSnS}_{4}$. Adv. Energy Mater. 2015, 5, 1-8.

(40) Sutter-Fella, C. M.; Stückelberger, J. A.; Hagendorfer, H.; La Mattina, F.; Kranz, L.; Nishiwaki, S.; Uhl, A. R.; Romanyuk, Y. E.; Tiwari, A. N. Sodium Assisted Sintering of Chalcogenides and Its Application to Solution Processed $\mathrm{Cu}_{2} \mathrm{ZnSn}(\mathrm{S}, \mathrm{Se})_{4}$ Thin Film Solar Cells. Chem. Mater. 2014, 26, 1420-1425.

(41) Grini, S.; Sopiha, K. V.; Ross, N.; Liu, X.; Bjørheim, T. S.; Platzer-Björkman, C.; Persson, C.; Vines, L. Strong Interplay between Sodium and Oxygen in Kesterite Absorbers: Complex Formation, Incorporation, and Tailoring Depth Distributions. Adv. Energy Mater. 2019, 9, 1-9.

(42) Haight, R.; Shao, X.; Wang, W.; Mitzi, D. B. Electronic and elemental properties of the $\mathrm{Cu}_{2} \mathrm{ZnSn}(\mathrm{S}, \mathrm{Se})_{4}$ surface and grain boundaries. Appl. Phys. Lett. 2014, 104, No. 033902-1.

(43) Andres, C.; Schwarz, T.; Haass, S. G.; Weiss, T. P.; Carron, R.; Caballero, R.; Figi, R.; Schreiner, C.; Bürki, M.; Tiwari, A. N.; Romanyuk, Y. E. Decoupling of Optoelectronic Properties from Morphological Changes in Sodium Treated Kesterite Thin Film Solar Cells. Sol. Energy 2018, 175, 94-100.

(44) Redinger, A.; Kretzschmar, S.; Unold, T. Quantitative PL Imaging of Thin Film Solar Cells-Potential and Pitfalls. 2017 IEEE 44th Photovoltaic Specialists Conference PVSC 2017, 1-4.

(45) Azzouzi, M.; Cabas-Vidani, A.; Haass, S. G.; Röhr, J. A.; Romanyuk, Y. E.; Tiwari, A. N.; Nelson, J. Analysis of the Voltage Losses in CZTSSe Solar Cells of Varying Sn Content. J. Phys. Chem. Lett. 2019, 10, 2829-2835.

(46) Larramona, G.; Levcenko, S.; Bourdais, S.; Jacob, A.; Choné, C.; Delatouche, B.; Moisan, C.; Just, J.; Unold, T.; Dennler, G. FineTuning the Sn Content in CZTSSe Thin Films to Achieve 10.8\% Solar Cell Efficiency from Spray-Deposited Water-Ethanol-Based Colloidal Inks. Adv. Energy Mater. 2015, 5, 1-10. 
(47) Hempel, H.; Hages, C. J.; Eichberger, R.; Repins, I.; Unold, T. Minority and Majority Charge Carrier Mobility in $\mathrm{Cu}_{2} \mathrm{ZnSnSe}_{4}$ revealed by Terahertz Spectroscopy. Sci. Rep. 2018, 8, 1-9.

(48) Hages, C. J.; Redinger, A.; Levcenko, S.; Hempel, H.; Koeper, M. J.; Agrawal, R.; Greiner, D.; Kaufmann, C. A.; Unold, T. Identifying the Real Minority Carrier Lifetime in Nonideal Semiconductors: A Case Study of Kesterite Materials. Adv. Energy Mater. 2017, 7, No. 1700167.

(49) Ratz, T.; Brammertz, G.; Caballero, R.; León, M.; Canulescu, S.; Schou, J.; Gütay, L.; Pareek, D.; Taskesen, T.; Kim, D.-H.; Kang, J.-K.; Malerba, C.; Redinger, A.; Saucedo, E.; Shin, B.; Tampo, H.; Timmo, K.; Nguyen, N. D.; Vermang, B. Physical Routes for the Synthesis of Kesterite. J. Phys. Energy 2019, 1, No. 042003.

(50) Scragg, J. J.; Ericson, T.; Kubart, T.; Edoff, M.; PlatzerBjörkman, C. Chemical Insights into the Instability of $\mathrm{Cu}_{2} \mathrm{ZnSnS}_{4}$ Films during Annealing. Chem. Mater. 2011, 23, 4625-4633.

(51) Redinger, A.; Berg, D. M.; Dale, P. J.; Siebentritt, S. The Consequences of Kesterite Equilibria for Efficient Solar Cells. J. Am. Chem. Soc. 2011, 133, 3320-3323.

(52) Clark, J. A.; Uhl, A. R.; Martin, T. R.; Hillhouse, H. W. Evolution of Morphology and Composition during Annealing and Selenization in Solution-Processed $\mathrm{Cu}_{2} \mathrm{ZnSn}(\mathrm{S}, \mathrm{Se})_{4}$. Chem. Mater. 2017, 29, 9328-9339.

(53) Shin, B.; Weber, J. R.; Long, R. D.; Hurley, P. K.; Van De Walle, C. G.; McIntyre, P. C. Origin and Passivation of Fixed Charge in Atomic Layer Deposited Aluminum Oxide Gate Insulators on Chemically Treated InGaAs Substrates. Appl. Phys. Lett. 2010, 96, 14.

(54) Redinger, A.; Levcenko, S.; Hages, C. J.; Greiner, D.; Kaufmann, C. A.; Unold, T. Time Resolved Photoluminescence on $\mathrm{Cu}(\mathrm{In}, \mathrm{Ga}) \mathrm{Se}_{2}$ absorbers: Distinguishing Degradation and Trap States. Appl. Phys. Lett. 2017, 110, No. 122104.

(55) Kirchartz, T.; Márquez, J. A.; Stolterfoht, M.; Unold, T. Photoluminescence-Based Characterization of Halide Perovskites for Photovoltaics. Adv. Energy Mater. 2020, 10, No. 1904134. 